\title{
Physico-Chemical and Bacteriological Characterization of an Ouéga-Fandji's Drilling Water in Benin
}

\author{
Virginie Gbohaida*, Buscotin Horax Beakou, Yaya Alain Koudoro, Cokou Pascal Agbangnan \\ Dossa, Felicien Avlessi, Dominique Codjo Koko Sohounhloue
}

Laboratory of Study and Research in Applied Chemistry, University of Abomey-Calavi, Abomey-Calavi, Benin

\author{
Email address: \\ virginie.gbohaida4@gmail.com (V. Gbohaïda) \\ ${ }^{*}$ Corresponding author
}

\section{To cite this article:}

Virginie Gbohaida, Buscotin Horax Beakou, Yaya Alain Koudoro, Cokou Pascal Agbangnan Dossa, Felicien Avlessi, Dominique Codjo Koko Sohounhloue. Physico-Chemical and Bacteriological Characterization of an Ouéga-Fandji's Drilling Water in Benin. Science Journal of Analytical Chemistry. Vol. 8, No. 2, 2020, pp. 60-64. doi: 10.11648/j.sjac.20200802.14

Received: March 13, 2020; Accepted: April 2, 2020; Published: May 27, 2020

\begin{abstract}
Water, potential source of life, must undergo various physico-chemical and bacteriological analyzes that will define its quality for human consumption in order to avoid the risk of water-borne diseases to consumers. Physico-chemical and bacteriological quality of an Ouega-Fandji's drilling water, use as drinking water, were investigated. Two (02) samples are constituted for the two analyzes' types. Twenty physico-chemical parameters ( $\mathrm{pH}$, Temperature, Electrical conductivity, Colour, Turbidity, Nitrites, Nitrates, Ammonium, Calcium, Magnesium, Total iron, Bicarbonates, Alcalinity, Chlorides, Sulphates, Fluorides, Iodides, Total hardness, Total Dissolved Solids) and three bacteriological parameters (Fecal coliforms, Total coliforms, Fecal streptococci) are evalued on samples. Some physical parameters (temperature, $\mathrm{pH}$, turbidity and conductivity) able to change during transport have been determined "in situ" using a portable multimeter (HANNA, HI 991300). The results obtained showed that unwanted substances (nitrites, nitrates, ammonium, fluorides, sulfates and iron) were almost absent. The physico-chemical parameters measured in this water sample comply with the quality standards for drinking water in Benin Republic. The conclusion is the same for bacteriological parameters, although the number of total coliforms (13 CFU) present in $100 \mathrm{~mL}$ of this water sample exceeds that recommended in Benin Republic. Therefore, disinfection of this water by the usual disinfection methods like chlorination with calcium hypochlorite is mandatory.
\end{abstract}

Keywords: Drilling, Drinking Water, Physico-chemical, Bacteriological

\section{Introduction}

Water, a potential life source, is one of the drivers of the organization and development of territories [1]. Unevenly distributed over the earth and present in sometimes limited quantities, it constitutes a major environmental issue [2]. The lack of sanitation infrastructure (presence of garbage dumps, latrines and not waterproof septic tanks) and the mismatch of the rainwater and wastewater disposal system make run a significant risk of contamination to aquifers. Also, the groundwater supply proceeds by vertical infiltrations of runoff from precipitation, and surface waters' infiltrations. The risks of their chemical and biological pollution depend on the one hand, on seepage water characteristics, and on the other hand, on the natural properties of the geological layers which separate the water table from the soil surface [3]. Therefore, water that is a life's source becomes disease source [4]. In developing countries, obtaining safe water for human consumption has become a serious problem due to an environmental protection lack [5]. Many parts of the world depend entirely on groundwater resources for various uses. Groundwater contaminated with various pollutants which make it unfit for consumption can endanger human and animal life as well as the environment as a whole. Specific concrete actions are therefore necessary to control the risk of water pollution and protect the natural quality of groundwater [6]. The problem related to the supply of drinking water is a key issue for African countries in general and those of West Africa in particular [7]. In Benin, almost a third of households use raining water as drinking water. $22.6 \%$ of 
households obtain water from unprotected wells and river water $(13.2 \%)$ which are sources of non-potable water. Households also are sourcing water fountain $(21.2 \%)$ and water from protected well $(8.3 \%)$ [8]. The non-permanent supply of drinking water by the national distribution network (SONEB) has led people to resort to ground and surface water. The chemical composition of water from the natural environment is very variable. It depends on the geological nature of the soil where it comes from and the reactive substances it encountered during the flow [9]. Degradation of groundwater resources has become a global concern in these last decades [10]. Groundwater has traditionally been the privileged water resource for drinking water production, as it's less vulnerable to pollution than surface water. Nevertheless, some minimum characteristics are required for them to be able to be used as drinking water. Drinking water must meet physico-chemical and biological quality standards [4]. The natural quality of the groundwater can be altered by anthropogenic activities or natural phenomena. In addition, apart from fresh water availability and associated anthropogenic factors, transport and storage significantly influence the quality of drinking water. The degree of quality required for water obviously depends on its use [11-12]. Abomey-Calavi's commune is one of the areas least served by the National Water Company of Benin (SONEB). Populations use water from drillings and wells without analysis. Therefore, many studies [13] were carried out on the quality of drilling or well water in Abomey-Calavi's commune and have shown that it's unfit for human consumption. There is few occurrences in literature of the assessment of Ouéga-Fandji's drilling water. The aim of this paper is to investigate the physico-chemical and bacteriological quality of this water.

\section{Material and Methods}

\subsection{Study Areas}

The water samples used for physico-chemical and bacteriological analysis was collected in "Ouéga Fandji" in Togba district at Abomey-Calavi's commune. The commune of Abomey-Calavi is a bar land's area, located in the Atlantic department in south of Benin between $6^{\circ} 26^{\prime} 54^{\prime \prime}$ North latitude and 2०21'20" East longitude [14].

\subsection{Sampling and Analysis}

The samples were taken in $0.5 \mathrm{~L}$ glass bottles with caps wrapped in aluminum paper and then sent to the laboratory for analysis. However, $\mathrm{pH}$, conductivity, TDS and temperature were measured "in situ" using a portable multimeter (HANNA, HI 991300). Bicarbonates, chlorides, calcium, magnesium and total hardness were measured by titrimetry while ammonium, color, total iron, iodides, nitrates, nitrites, sulfates and fluorides were determined by a spectrophotometer of HACH DR/2400 type in accordance with the analysis methods of the French Association for Standardization, AFNOR [15-16]. Fecal streptococci, fecal coliforms and total coliforms were the main microbiological parameters sought. These germs were determined by the membrane filtration method as described in [16]. This method is widely used for the enumeration of microorganism germs in water intended for human consumption.

\section{Results and Discussion}

\subsection{Physical Parameters}

Physical parameters such as $\mathrm{pH}$, electrical conductivity, temperature, color and turbidity presented the results in Table 1. The $\mathrm{pH}$ of the water analyzed is 7.02 . This $\mathrm{pH}$ value is well within the allowed $\mathrm{pH}$ range of $6.5-8.5$. The temperature of a water plays a determining role in the modification of the physical and chemical properties of water. Indeed, it influences its density, the solubility of gases, the dissociation of dissolved salts, the biochemical and biological reactions that occur in water [17]. The temperature of $26.7^{\circ} \mathrm{C}$ obtained is slightly higher than the standard. This could be attributed to the fact that the water temperature depends on the time of its withdrawal and is intimately linked to the ambient temperature at withdrawal time [1]. Water temperature has no direct impact on human health. However, a high temperature (above $20{ }^{\circ} \mathrm{C}$ ), like that of the waters studied, promotes microorganisms development [18]. The analysis of water color shows that the water isn't very colored with $01 \mathrm{CU}$ for color value. It meets the maximum standard required which is $15 \mathrm{CU}$. The color value obtained is lower than those obtained in [19]. Their investigations on well water in Congo Brazzaville revealed color values between 7 and 10. The established turbidity standard is 5 NTU. The water sample analyzed showed no turbidity. This turbidity obtained meets the required standard and is identical to that in our investigations into drinking water of Dassa Zoume [1]. The electrical conductivity reflects the degree of overall mineralization. It informs about the salinity rate [20]. The conductivity of water is the measure of its ability to conduct electrical current. It varies with temperature and is related to the concentration and nature of the dissolved substances (TDS) in the sample [21]. In fact, the higher the conductivity, more strongly the water is mineralized. The electrical conductivity of $33 \mu \mathrm{S} / \mathrm{cm}$ obtained is below maximum standard $(2000 \mu \mathrm{S} / \mathrm{cm})$. This conductivity result is close to those obtained in [22] on well water from Lagos in Nigeria with conductivity values between 22 and $315 \mu \mathrm{S} / \mathrm{cm}$. However, this result is contrary to those in [23]. They obtained conductivities higher than the norm in the wells of Lome in Togo.

Table 1. Physical parameters of drinking water.

\begin{tabular}{lll}
\hline Parameters & Values & Benin Standards \\
\hline $\mathrm{pH}$ & 7.02 & $6.5-8.5$ \\
Temperature $\left({ }^{\circ} \mathrm{C}\right)$ & 26.7 & $\approx 25$ \\
Electrical conductivity $(\mu \mathrm{S} / \mathrm{cm})$ & 33 & 2000 \\
Color $(\mathrm{CU})$ & 01 & 15 \\
Turbidity $(\mathrm{NTU})$ & 00 & $\geq 5$ \\
\hline
\end{tabular}




\subsection{Chemical Parameters}

\subsubsection{Nitrogenous Mineral Compounds}

The nitrogenous mineral compounds investigated revealed very small quantities (Table 2). It confirms the good quality of this water. Unwanted substances (nitrites, nitrates, ammonium, fluorides, sulfates and iron) were almost absent. The enrichment of water in nitrates results from diffuse pollution linked to the percolation of rainwater from cultivated soils and to point pollution caused by direct infiltration of wastewater. In general, the presence of nitrates "very soluble in water" comes from agriculture, discharges from local communities and industry. Nitrates are today the major cause of groundwater pollution [24]. The low quantities of nitrogen and phosphate mineral compounds previously obtained from the water distributed by SONEB confirmed the good quality of this water [1].

Table 2. Characteristic parameters of nitrogen in drinking water.

\begin{tabular}{lll}
\hline Nitrogen & Content $(\mathbf{m g} / \mathbf{L})$ & Standards in Benin \\
\hline Nitrous $\left(\mathrm{NO}_{2}^{-}\right)$ & 0.0 & 0.1 \\
Nitric $\left(\mathrm{NO}_{3}^{-}\right)$ & 0.18 & 45 \\
Ammonia $\left(\mathrm{NH}_{4}^{+}\right)$ & 0.0 & 0.5 \\
\hline
\end{tabular}

\subsubsection{Other Physico-Chemical Analysis}

Table 3 presents the results of some physico-chemical analysis carried out on the water sample taken. This sample contains dissolved ions, the main ones being calcium, magnesium and bicarbonates. These ions essentially come from soils' leaching by rainwaters. Their content depends directly on rocks' nature [24]. The results show that the essential substances (calcium, magnesium) are generally in low concentrations respectively $0.8016 \mathrm{mg} / \mathrm{L}$ and 0.7296 $\mathrm{mg} / \mathrm{L}$ compared to the accepted standards. The hardness of a water is linked to the geological nature of the terrain crossed and reflects its content of calcium and magnesium salts. It results in precipitation of the scum of the soap or its excessive use during cleaning activities [25]. The sample had a total hardness of $5 \mathrm{mg} / \mathrm{L}, 100$ times lower than the standard $(500 \mathrm{mg} / \mathrm{L})$. The alkalinity value obtained is $10 \mathrm{mg} / \mathrm{L}$. Indeed, bicarbonates constitute the main part of the water alkalinity observed. They can come from the dissolution of carbonate formations depending on the reaction: $\mathrm{CaCO}_{3}+$ $\mathrm{H}_{2} \mathrm{O} \rightarrow 2 \mathrm{HCO}_{3}^{-}+\mathrm{Ca}^{2+}$ [29]. According to [25], carbon dioxide $\left(\mathrm{CO}_{2}\right)$ present in the soil or in the atmosphere is the main source of alkalinity in groundwater or surface water. The analysis revealed a concentration of iodides of 0.04 $\mathrm{mg} / \mathrm{L}$. Iodine is a mineral and a trace element, the deficiency of which leads disturbances that cause brain damage, cretinism, and lead to miscarriages, reduced fertility and goiter. These disorders constitute the most important cause of mental retardation and also the easiest to prevent [1]. Total dissolved solids (TDS) report the mineral amount in the water. The concentration of TDS in water varies considerably in different geological regions due to the difference in solubility of minerals [26]. The dissolved solids (TDS) content expresses the total concentration of dissolved substances in water. TDS is composed of inorganic salts and some organic matter [21]. The water analyzed presented a TDS of 33, a value below the required standard. In general, the investigated drinking water presented a physico-chemical quality in accordance with Benin standards.

Table 3. Some physico-chemical parameters of drinking water.

\begin{tabular}{lll}
\hline Parameters & Contents $(\mathbf{m g} / \mathbf{L})$ & Benin Standards \\
\hline Calcium $\left(\mathrm{Ca}^{2+}\right)$ & 0.80 & 100 \\
Magnesium $\left(\mathrm{Mg}^{2+}\right)$ & 0.73 & 50 \\
Iron (Total iron) & 0.08 & 0.3 \\
Bicarbonates $\left(\mathrm{HCO}_{3}{ }^{-}\right)$ & 6.1 & - \\
Alcalinity in $\mathrm{CaCO}_{3}$ & 10 & - \\
Chlorides $\left(\mathrm{Cl}^{-}\right)$ & 0 & 250 \\
Sulfates $\left(\mathrm{SO}_{4}{ }^{2-}\right)$ & 0 & 500 \\
Fluorides $\left(\mathrm{F}^{-}\right)$ & 0.0 & 1.5 \\
Iodides $\left(\mathrm{I}^{-}\right)$ & 0.04 & - \\
Total hardness & 05 & 500 \\
TDS & 33 & 2000 \\
\hline
\end{tabular}

TDS: Total Dissolved Solids

\subsection{Bacteriological Parameters}

Table 4 presents the results of the bacteriological tests carried out on the water sample taken. Bacteriologically, the water has been found to be contaminated with total coliforms. The other two germs (Fecal coliforms and Fecal streptococci) are not detected there. The standards require the total absence of germs indicating fecal contamination in water intended for human consumption [20]. This is observed in the sample studied. The presence of total coliforms doesn't constitute an immediate health risk (quality standards for drinking water in Benin Republic 2001) [21]. So therefore, the bacteriological quality degree of this water is acceptable. However, the number of total coliforms present in this sample exceeds that recommended by the quality standards for drinking water in the Republic of Benin. It is therefore important to disinfect this water by the usual methods of disinfection as chlorination based on calcium hypochlorite or sometimes with bleach, the active ingredient of which is sodium hypochlorite. The investigations on the bacteriological quality of water of well and drilling have done in Lome. Analyzed drilling water is less contaminated compared to wells' water because of the difference between the depth of wells and that of drilling [27]. Indeed, boreholes in Lome are carried out in neighborhoods where it is more difficult for residents to make wide diameter wells. Because of the relief and the nature (sandy clay) of the soil, access to water in this area is through drilling at depths that go on average beyond 30 meters [27]. This observation is frequent in this study area. Furthermore, The investigations into groundwater had shown that the boreholes in the city of Bembèrèkè have acceptable bacteriological quality [28].

Table 4. Bacteriological parameters of drinking water.

\begin{tabular}{lll}
\hline Parameters & Values in $\mathbf{1 0 0} \mathbf{~ m L}$ & Standards in Benin \\
\hline Fecal coliforms & 13 & 10 \\
Total coliforms & 0 & 0 \\
Fecal streptococci & 0 & 0 \\
\hline
\end{tabular}




\section{Conclusion}

The physicochemical parameters measured in this drinking water sample comply with the quality standards of drinking water in the Republic of Benin. From microbiological analysis, the number of total coliforms present in this sample exceeds that recommended by the quality standards for drinking water in Benin. It's therefore important to disinfect this water by usual disinfection methods as chlorination based on calcium hypochlorite or sometimes with bleach, the active principle of which is sodium hypochlorite. The drinking water available in this locality has proven to be of good bacteriological quality due to the total absence of germs indicating faecal contamination in this water.

\section{References}

[1] V. Gbohaïda, D. C. P. Agbangnan, M. B. Ngossanga, S. E. Medoatinsa, L. F. C. Dovonon, D. V. Wotto, F. Avlessi, D. C. K. Sohounhloue. "Etude de la qualité physico-chimique de l'eau de boisson dans deux localités du Bénin: Cotonou et Dassa-Zoumè". Int. J. Biol. Chem. Sci. 2016. 10 (1): 422-434.

[2] L. F. C. Dovonon, H. H. Soclo, M. A. N. Gbaguidi, A. Youssao. "Utilisation des os calcinés dans la défluoruration des eaux contaminées: Détermination expérimentale de la température de calcination et de la granulométrie optimales des os". Int. J. Biol. Chem. Sci. 2011. 5 (4): 1712-1726.

[3] I. Moussa Nomao. Évaluation de la qualité physico-chimique et Bactériologique des eaux des forages à usage particulier et semi-industriels à Ouagadougou (Burkina Faso). Mémoire de Master en Eau et Assainissement, 2iE Ouagadougou, Burkina Faso (2017), 90.

[4] C. Bakouan, B. Guel, A.-L. Hantson. "Caractérisation physico-chimique des eaux des forages des villages de Tanlili et Lilgomdé dans la région Nord du Burkina Faso Corrélation entre les paramètres physico-chimiques". Afrique Science. 2017. 13 (6): 325-337.

[5] J. P. Mehounou, R. G. Jossè, P. Dossou-Yovo, S. F. Senou, R. M. Toklo. "Caractérisation physico-chimique et microbiologique des eaux souterraines et superficielles dans la zone de production cotonnière d'Aplahoué". Journal of Applied Biosciences. 2016. 103: 9841-9853.

[6] B. Raheli-Namin, S. Mortazavi, M. Mobinifar, M. Adeli. "Groundw-quality probability mapping and assessment for domestic and irrigation purposes in Ghara-su Basin of Golestan Province, Iran". J. Mater. Environ. Sci. 2016.7 (1): 259-271.

[7] L. Odoulami, F. Gbesso, S. Hounguevou. "Qualité de l'eau de consommation et maladies hydriques dans la commune de Zè (Bénin)". Revue de Géographie Tropicale et d'Environnement. 2013. 2: 104-113.

[8] M. Lagnika, M. Ibikounle, J. C. Montcho, V. D. Wotto, N. G. Sakiti. "Caractéristiques physico-chimiques de l'eau des puits dans la commune de Pobè (Bénin, Afrique de l'ouest)". J. of Appl. Biosci. 2014. 79: 6887-6895.

[9] T. K. Yao, M. Oga, O. Fouché, D. Baka, C. Pernelle and J. Biemi. "Évaluation de la potabilité chimique des eaux souterraines dans un bassin versant tropical: cas du Sud-Ouest de la Côte d'Ivoire". Int. J. Biol. Chem. Sci. 2012. 6 (6): 70697086.

[10] S. Guergazi, K. Yahiaoui, D. Amimeur and S. Achour. "Impact of the chlorination process on the quality of Algerian surface Waters". J. Mater. Environ. Sci. 2014. 5: 2354-2358.

[11] R. C. Johnson, G. Boni, H. Amoukpo, Y. Barogui, G. Diez, D. Agossadou, G. E. Sopoh, M. Boko. "Microbiological Quality Assessment of Drinking Water in Lalo Commune, Benin (West Africa)". Journal of Water Resource and Protection. 2016. 8: 816-822.

[12] B. Festy, P. Hartemann, M. Ledrans, P. Levallois, P. Payment, D. Tricard. (2003). Qualité de l'eau, In: Environnement et santé publique - Fondements et pratiques, 333-368.

[13] C. Dégbey, M. Makoutode, E.-M. Ouendo, B. Fayomi, C. De Brouwer. "La qualité de l'eau de puits dans la commune d'Abomey-Calavi au Bénin". Environnement, Risques et Santé. 2008.7 (4): 279-283.

[14] V. Gbohaïda. Production et caractérisation de bioénergie par fermentation alcoolique d'agro-ressources non conventionnelles sucrières et lignocellulosiques du Bénin (pomme cajou et épluchures d'ananas). Thèse de doctorat, Université d'Abomey-Calavi, (2017), 214.

[15] AFNOR (Association Française de Normalisation). In Afnor (Eds) Recueil des normes françaises, 1986, Paris.

[16] J. Rodier, Legude B., Merlet N. et coll. 2009. L'analyse de l'eau. 9th Edition. Dunod. 1579.

[17] A. Akil, T. Hassan, E. H. Fatima, B. Lahcen, L. Abderrahim. Etude de la qualité physico-chimique et contamination métallique des eaux de surface du bassin versant de Guigou, Maroc (2014), 11.

[18] T. A. Barhé, F. Bouaka. "Caractérisation Physicochimique et Chloration des Eaux de Puits consommées dans la Ville de Brazzaville-Congo" VJ. Mater. Environ. Sci. 2013. 4 (5): $605-$ 612.

[19] M. E. K. Ould Cheikh, K. El Kacemi, L. Idrissi. "Caractérisation physico-chimique des eaux d'alimentation de la ville de Tijikja (Mauritanie)". Int. J. Biol. Chem. Sci. 2011. 5 (5): 2133-2139.

[20] R. G. Jossè, P. Dossou Yovo, E. Sagbo, K. J. Dalohoun, S. Bassa, N. Topanou, J. Fatombi. "Caractérisation physicochimique et microbiologique de L'eau de process à la Société béninoise des brasseries (SOBEBRA)". Annales des Sciences Agronomiques. 2011. 15 (1): 51-65.

[21] J. O. Adejuwon, C. J. Mbuk. "Biological and physicochemical properties of shallow wells in Ikorodu town, Lagos Nigeria". Journal of Geology and Mining Research. 2011. 3 (6): 161168.

[22] L. Tampo, M. Ayah, T. Kodom, I. Tchakala, P. Boguido, L. Bawa, B. Djaneye. "Impact de la demande en chlore et de la chloration sur la désinfection des eaux de puits des quartiers de Lomé: cas des quartiers de Démakpoé et d'Agbalépédogan (Togo)". Journal of Applied Biosciences. 2014. 75: 62726281.

[23] A. F. Lanjri, J. Brigui, A. El Cadi, M. Khaddor, F. Salmoune. "Caractérisation physico-chimique et bactériologique des eaux souterraines de Tanger". Mater. Environ. Sci. 2014. 5 (S1): 2230-2235. 
[24] O. Frantzy. Étude de la qualité de l'eau destinée à la consommation humaine dans le sous-bassin versant de Ravine Diable (Anse-à-Veau). Mémoire de Master, Faculté des Sciences, Université Catholique de Louvain (2017), 85.

[25] R. Madi Bamdou. Potabilisation des eaux de consommation par photo Fenton. Mémoire d'Ingénieur, 2iE Ouagadougou, Burkina Faso (2010), 65.

[26] K. Soncy, B. Djeri, K. Anani, M. Eklou-Lawson, Y. Adjrah, D. S. Karou, Y. Ameyapoh et C. de Souza. "Évaluation de la qualité bactériologique des eaux de puits et de forage à Lomé, Togo". Journal of Applied Biosciences. 2015. 91: 8464-8469.
[27] S. F. R. O. Senou, R. G. Josse, R. M. Toklo, K. J. Fatombi, N. Topanou, and B. Coulomb. "Caractérisation physico-chimique et bactériologique des eaux souterraines de la ville de Bembèrèkè au Nord-Est du Bénin". International Journal of Innovation and Applied Studies. 2018. 23 (1): 1-9.

[28] A. A. Mahamane, B. Guel. "Caractérisations physicochimiques des eaux souterraines de la localité de Yamtenga (Burkina Faso)". Int. J. Biol. Chem. Sci. 2015.9 (1): 517-533. 